\title{
Physiochemical Characteristics of Buffalo Milk Samples Available in Four Districts of Chhattisgarh, India
}

\author{
Choodamani Chandrakar ${ }^{1}$, Praveen Kumar $^{1}$, Sanjay Shakya ${ }^{1}$, Sudhir Kumar Jaiswal ${ }^{2}$, \\ Monika $^{3}$, UpendraWasist ${ }^{4}$ and Sambhuti Shankar Sahu ${ }^{5}$ \\ ${ }^{1}$ Department of Veterinary Public Health and Epidemiology, \\ ${ }^{3}$ Department of Veterinary Pharmacology and Toxicology, ${ }^{4}$ Department of Livestock and \\ Production Management, College of Veterinary Science and Animal Husbandry, \\ Anjora, Durg, (C.G.) 491001, India \\ ${ }^{2}$ Division of poultry Science, Indian Veterinary Research Institute, Izatnagar, \\ Bareilly, U.P.(243 122), India \\ ${ }^{5}$ Department of Livestock Production and Management, College of Veterinary Science and \\ Animal Husbandry, Bilaspur, 495001, Chhattisgarh, India \\ *Corresponding author
}

\begin{tabular}{|l|}
\hline K e y w o r d s \\
Buffalo, Lactose, \\
SNF, Correlation
\end{tabular}

\section{Introduction \\ Milk is one of the most important foods of human beings. It is universally recognized as a complete diet due to its essential \\ components like proteins, lactose, milk fat, minerals and vitamins in a highly digestible form and is recommended as compulsory part of daily diet for the expectant mothers as well as growing children (Javaid et al., 2009). The}

The present study was designed to see quality of raw buffalo milk in four districts of Chhattisgarh and the effect of different location, stage of lactation and parity on milk components of buffaloes. Total 112 milk samples were collected, comprised of four different districts and from lactation stage (early, mid and late) and from varying parity of (1, 2, 3 and 4 above) for the study. Overall milk fat, solid not fat (SNF), protein, lactose, density, freezing point and ash were observed to be $6.50 \pm 0.05,8.88 \pm 0.03,3.71 \pm 0.03$, $4.90 \pm 0.06,1.030 \pm 0.002,-0.534 \pm 0.002$ and $0.81 \pm 0.004 \%$, respectively. Durg districts reported highest for milk at and SNF than other districts. Mean fat content was in FSSAI prescribed level but SNF content is recorded below FSSAI level. Stage of lactation had also significant effect on milk components; milk fat and protein percent increased significantly with the advancement of lactation stage significantly $(\mathrm{P}<0.05)$. Milk fat during early, mid and late lactation was $6.31 \pm 0.09,6.55 \pm 0.07$ and $6.61 \pm 0.09 \%$; protein was $3.61 \pm 0.05,3.65 \pm 0.05$ and $3.83 \pm 0.06 \%$ respectively $(\mathrm{P}<0.05)$. Milk fat and protein levels were more in advance parities indicating significant effect of parity on milk composition. Data on levels of milk constituents varying over the lactation stages, parities and correlation between milk constituents in buffaloes were important phenotype indices for developing genomic selection programme in buffaloes. 
minimum standards for market milks are fixed for fat and SNF contents to ensure quality milk supply to the consumers and to prevent adulteration of milk. Unfortunately, due to unorganized and nonregulated marketing system, the quality of milk is hardly maintained at consumer level. Addition of water and ice is common which affects the physical as well as chemical quality of milk by altering the proportion of different constituents.

All most all nutrients are also richer in buffalo milk (high content of fat, lactose, protein and ash percent) hence getting more attention and fetches higher price compared to cow milk (Abd El-Salam and El-Shibiny, 2011). In India, milk price is generally fixed based on fat content together with volume. Hence, while procuring milk from farmers in cooperatives, milk was tested for fat percent. However, with the advancement of technology and availability of cost effective milk analyzer, now-a-days it is also possible to measure other milk components such as protein, lactose, ash, SNF and TS (Ravikala et al., 2014). Milk composition is considered as an important attribute essential for dairy farmers to maintain raw milk worth, dairy industries to produce better quality products (Malek dos Reis et al., 2013). Although, several factors affect milk composition in buffaloes, stage of lactation and seasonal availability of nutrition play crucial role (Ravikala et al., 2014) and subsequently affect the milk products' quality. Thus, a large segment of population is deprived of the consumption of energetic milk.

Milk supply in Chhattisgarh takes place through different marketing channels i.e. direct sellers, milk collection centers, milk vendor shops and hotels and dairy farms from the surrounding areas, and is based on unorganized marketing system. Thus keeping this in view, the present study present study was designed to know the compositional quality of buffalo raw milk in four districts of Chhattisgarh.

\section{Materials and Methods}

The study was carried out at College of Veterinary Scienceand Animal Husbandry, Chhattisgarh Kamdhenu University, Durg, Chhattisgarh, India. A total of 112 buffalo milk collected that were in different parity and stage of lactation were collected from the livestock owners and dairy unit of Durg, Rajnandgaon, Raipur and Balod districts of Chhattisgarh. About $50 \mathrm{ml}$ of milk sample were collected in aseptic conditions randomly without any known bias. The milk samples were analyzed various traits of milk composition content by by LactoStar SN 3510.The stage of lactation is recorded and was grouped into early, mid and late lactations. Parity on the test day (i.e. order of lactation) was also considered as one of the factors influencing milk composition.

\section{Statistical analysis}

A multivariate analysis (Johnson and Wichern 2002) of variance was performed to observe pair wise mean differences in milk composition over different sources of variation i.e. district, parity and stage of lactation using Duncan multiple range test, difference was considered as significant if $\mathrm{p}<0.05$ and the results were presented as Mean \pm SE.

\section{Results and Discussion}

\section{Physico-chemical properties of milk}

\section{Milk fat percentage}

Milk samples from Durg districts tested highest for fat percentage $(6.68 \pm 0.07)$ while that of Rajnandgaon was lowest $(6.35 \pm 0.10)$ 
(Table 1). There was a significant difference $(\mathrm{P}<0.05)$ in fat $\%$ among the study districts and the overall mean value of the fat $(6.50 \pm 0.05 \%)$ in the study districts which is higher than FSSAI prescribed value (6.0\%). But about $30 \%$ of milk was found below the FSSAI recommended value. Parity and stage of lactation had significant effect on milk fat $\%$ (Table 1). The variation of milk fat percent remained within the normal range in buffaloes i.e. 5.3-9.0\% (Abd El-Salam and El-Shibiny, 2011; Claeys et al., 2014). The milk fat percent increased significantly from early lactation to late lactation which is in agreement with the report of Yadav et al., (2013) and Patbandha et al., (2016). However, Garaniya et al., (2013) did not observe any difference statistically among different stages of lactation, though milk fat percent increased gradually with advancement of lactation. No specific trend is ascribed to change in level of milk Fat \%. Increase in fat is associated with enhanced milk yield with advancing parity up to fourth and above parity.

\section{Milk solids not fat percentage (SNF):}

The overall average for SNF percentage was $8.88 \pm 0.03$ and the multivariate analysis of variance revealed that centre had very significant effect on SNF $(\mathrm{P}<0.05)$ whereas stage of lactation had no significant effect on these parameters but parity has significant effect on the SNF content but trend was not specific. Mean SNF content of different districts are below the FSSAI prescribed except Durg district. However, Abd El-Salam and El-Shibiny (2011) reported milk SNF value as $8.3-10.4 \%$ in buffaloes and same being supported by our result. We did not observe any significant effect of season (Table 1) or stage of lactation on milk SNF content ( $\mathrm{p}>0.05)$. Patbandha et al., (2016) reported similar findings however, Dubey et al., (1997) reported effect of stage of lactation on milk SNF level. Topographical peculiarities and difference in feed ingredients must have resulted in such a significant difference between districts. A proximate analysis of these feeds will reveal imbalances if any, which should be corrected.

\section{Milk protein and lactose content}

The milk protein percent varied from 3.58$3.87 \%$ between different districts (Table 1) and $3.61-3.83 \%$ during different stages of lactation which is in agreement with the previous report in buffaloes (Garaniya et al., 2013). The protein percent in present study was in accordance with the findings of the Dubey et al., (1997) and Yadav et al., (2013) they reported protein percent in the buffaloes i.e. $3.5-3.8 \%$. Milk protein levels vary significantly over the different parities.Increased protein level was recorded in third and above parities. Yadav et al., (2013) also reported non-significant increase in milk protein percent with the advancement of parity but after seventh parity.

The mean lactose percent during different season, during different lactation stage and in different parity are depicted in Table 1 respectively. The overall milk lactose percent observed in the present study was found to be $4.90 \%$ which is in comparable range reported by Mahmood and Usman, 2010; Abd ElSalam and El-Shibiny, 2011; Ahmad et al., 2013 in buffaloes. In the present study we observed a significant difference in lactose content of different districts but parity and stage of lactation had no significant effect on milk lactose \%.Though previous studies observe effect of parity and lactation stage on lactose content of buffalo milk (Yadav et al., 2013; Patbandha et al., 2016).The lower lactose might be associated with higher somatic cell counts which is a indicator of mammary infection (Malek dos Reis et al., 2013). 
Table.1 Least square means (Mean \pm SE) of milk constituents

\begin{tabular}{|c|c|c|c|c|c|c|c|c|}
\hline Source & $\begin{array}{l}\text { Number } \\
\text { of } \\
\text { Samples } \\
\text { (N) }\end{array}$ & Fat $(\%)$ & SNF (\%) & Protein $(\%)$ & Lactose $(\%)$ & $\begin{array}{l}\text { Density } \\
\left(\mathrm{g} / \mathrm{cm}^{3}\right)\end{array}$ & $\begin{array}{l}\text { Freezing Point } \\
\left({ }^{0} \mathrm{C}\right)\end{array}$ & $\begin{array}{l}\text { Minerals } \\
(\%)\end{array}$ \\
\hline \multicolumn{9}{|l|}{ District } \\
\hline Durg & 28 & $6.68^{a} \pm 0.07$ & $9.07^{\mathrm{a}} \pm 0.06$ & $3.75^{\mathrm{ab}} \pm 0.06$ & $4.95^{\mathrm{ab}} \pm 0.05$ & $1.031^{\mathrm{a}} \pm 0.0002$ & $-0.523^{c} \pm 0.003$ & $0.82^{\mathrm{a}} \pm 0.006$ \\
\hline $\begin{array}{l}\text { Ranandgao } \\
\text { n }\end{array}$ & 28 & $6.35^{b} \pm 0.10$ & $8.74^{\mathrm{b}} \pm 0.06$ & $3.64^{b} \pm 0.06$ & $5.19^{\mathrm{a}} \pm 0.18$ & $1.029^{b} \pm 0.0004$ & $-0.545^{\mathrm{a}} \pm 0.004$ & $0.79^{b} \pm 0.009$ \\
\hline Raipur & 28 & $6.53^{\mathrm{ab}} \pm 0.11$ & $8.79^{b} \pm 0.07$ & $3.87^{\mathrm{a}} \pm 0.08$ & $4.82^{\mathrm{b}} \pm 0.10$ & $1.031^{\mathrm{a}} \pm 0.0003$ & $-0.539^{\mathrm{ab}} \pm 0.005$ & $0.80^{\mathrm{ab}} \pm 0.009$ \\
\hline Balod & 28 & $6.44^{\mathrm{ab}} \pm 0.12$ & $8.92^{\mathrm{ab}} \pm 0.07$ & $3.58^{\mathrm{b}} \pm 0.07$ & $4.65^{b} \pm 0.11$ & $1.030^{\mathrm{a}} \pm 0.0003$ & $-0.529^{b c} \pm 0.003$ & $0.82^{\mathrm{a}} \pm 0.005$ \\
\hline $\begin{array}{l}\text { Overall } \\
\text { mean }\end{array}$ & 112 & $6.50 \pm 0.05$ & $8.88 \pm 0.03$ & $3.71 \pm 0.03$ & $4.90 \pm 0.06$ & $1.030 \pm 0.0002$ & $-0.534 \pm 0.002$ & $0.81 \pm 0.004$ \\
\hline \multicolumn{9}{|l|}{ Parity } \\
\hline 1 & 33 & $6.25^{c} \pm 0.08$ & $8.72^{\mathrm{b}} \pm 0.06$ & $3.63^{\mathrm{b}} \pm 0.05$ & $4.98 \pm 0.17$ & $1.030 \pm 0.0003$ & $-0.536 \pm 0.003$ & $0.81 \pm 0.008$ \\
\hline 2 & 32 & $6.63^{\mathrm{ab}} \pm 0.08$ & $8.94^{\mathrm{a}} \pm 0.06$ & $3.63^{\mathrm{b}} \pm 0.06$ & $4.79 \pm 0.10$ & $1.030 \pm 0.0003$ & $-0.533 \pm 0.004$ & $0.80 \pm 0.008$ \\
\hline 3 & 24 & $6.43^{b c} \pm 0.10$ & $8.90^{\mathrm{ab}} \pm 0.08$ & $3.74^{\mathrm{ab}} \pm 0.06$ & $4.88 \pm 0.08$ & $1.030 \pm 0.0004$ & $-0.529 \pm 0.003$ & $0.81 \pm 0.008$ \\
\hline 4 and above & 23 & $6.75^{\mathrm{a}} \pm 0.15$ & $9.00^{\mathrm{a}} \pm 0.07$ & $3.92^{\mathrm{a}} \pm 0.10$ & $4.98 \pm 0.08$ & $1.030 \pm 0.0005$ & $-0.538 \pm 0.005$ & $0.80 \pm 0.009$ \\
\hline \multicolumn{9}{|c|}{ Stages of lactation } \\
\hline $\begin{array}{l}\text { Early ( } 5 \text { to } \\
90 \text { days) }\end{array}$ & 34 & $6.31^{b} \pm 0.09$ & $8.84 \pm 0.06$ & $3.61^{\mathrm{b}} \pm 0.05$ & $4.89 \pm 0.16$ & $1.031 \pm 0.0003$ & $-0.535 \pm 0.004$ & $0.81 \pm 0.005$ \\
\hline $\begin{array}{l}\text { Mid (91 to } \\
180 \text { days) }\end{array}$ & 33 & $6.55^{\mathrm{ab}} \pm 0.07$ & $8.85 \pm 0.06$ & $3.65^{\mathrm{b}} \pm 0.05$ & $4.87 \pm 0.08$ & $1.030 \pm 0.0004$ & $-0.535 \pm 0.003$ & $0.81 \pm 0.008$ \\
\hline $\begin{array}{l}\text { Late (above } \\
181 \text { days) }\end{array}$ & 45 & $6.61^{\mathrm{a}} \pm 0.09$ & $8.93 \pm 0.05$ & $3.83^{\mathrm{a}} \pm 0.06$ & $4.94 \pm 0.07$ & $1.030 \pm 0.0004$ & $-0.532 \pm 0.003$ & $0.80 \pm 0.006$ \\
\hline
\end{tabular}


Table.2 Pearson correlation coefficients between different milk constituents in different districts; $\mathrm{N}=112$

\begin{tabular}{|l|l|l|l|l|l|l|l|}
\hline Variable & Fat & SNF & Protein & Lactose & Density & Minerals & $\begin{array}{l}\text { Freezing } \\
\text { Point }\end{array}$ \\
\hline Fat & 1 & $0.500 * *$ & $0.527 * *$ & $-0.186^{*}$ & 0.003 & 0.102 & 0.027 \\
\hline SNF & & 1 & $0.194^{*}$ & -0.113 & 0.161 & -0.023 & 0.083 \\
\hline Protein & & & 1 & 0.052 & 0.122 & 0.032 & 0.013 \\
\hline Lactose & & & 1 & -0.125 & $-0.253^{* *}$ & -0.094 \\
\hline Density & & & & & 1 & 0.062 & 0.086 \\
\hline Minerals & & & & & & 1 & 0.072 \\
\hline Freezing & & & & & & & \\
\hline Point & & & & & & & \\
\hline
\end{tabular}

** Pearson Correlation is significant at the 0.01 level (2-tailed) 
Milk density, ash content and freezing point

According to the study results, the mean density, ash content and freezing point of the raw milk samples from the buffalo were $1.030 \pm 0.0002,0.81 \pm 0.004$ and $-0.534 \pm 0.002$ ${ }^{\circ} \mathrm{C}$ respectively. The density value was lower than the findings of some previous research results (Padghan et al., 2008; Braun and Preuss, 2008).The present results are similar to this standard. This value $(1029 \pm 0.056 \mathrm{~g} / \mathrm{cm}$ 3 ) is lower than findings of Franciscis et al.(1988) and similar to the results of Zaman et al.(2007) and Sahin et al., (2014).

Recently, Abd El-Salam and El-Shibiny (2011) and Claeys et al., (2014) reviewed the composition of buffalo milk and reported that ash content in milk varied between 0.71 to $0.85 \%$ and 8.0 to $9.0 \%$, respectively which is agreement of the present findings. In this experiment, the average freezing point was determined as $-0.55{ }^{\circ} \mathrm{C}$ in milk samples. Similarly Sahin et al., (2014) reported that the buffalo milk freezing point was -0.52 to -0.56 ${ }^{\circ} \mathrm{C}$. The density is mainly due to the water content present in the sample. Furthermore, it is a measure that provides information about the purity of the raw milk.

The freezing point of raw milk is an important feature to determine the amount of water added (Aydin et al., 2010) as milk is more diluted, the freezing point will raise closer to zero.The stage of lactation and parity did not affect the milk density, ash content and freezing point in buffalo milk, but we observe a significant $(\mathrm{P}<0.05)$ effect of different location on of these parameters. The results of the present investigation are in agreement with the findings of some researchers (Zaman et al., 2007). However, Sahin et al., (2014) reported that the stage of lactation and parity of buffalo milk density was significant.

\section{Correlation coefficient between different} milk constituents

In the present study, Table 2 shows correlation coefficients between different constituents of milk. In this study, highly significant $(\mathrm{P}<0.01)$ correlation was observed between fat and SNF (0.500), fat and protein $(0.527)$ but we observed a significant $(\mathrm{P}<0.01)$ negative correlation between fat and lactose (-0.186). Correlation between SNF with protein (0.194) and lactose (0.113) were found to be positive and significant $(\mathrm{P}<0.05)$ with protein. In between protein and lactose a non- significant positive correlation (0.052) was observed. Density of milk showing positive correlation with all the milk constituents except with lactose (-0.125). In respect of freezing point we observed a negative correlation with SNF and highly significant $(\mathrm{P}<0.01)$ negative correlation with lactose content $(0.253)$ except these all milk constituents showing positive correlation. Ash content of milk showing positive correlation with all the milk constituents except with lactose.Similarly Gâjâilă et al., (2014) reported positive and highly significant correlation between fat and protein and a negative correlation between fat and lactose in buffalo milk. However Hamad et al., (2014) reported a highly significant negative correlation between fat and SNF and protein content. These findings are suggested that selection for fat will automatically increase different constituents of milk.

In conclusion, results of the present study indicate that different location, stage of lactation and parity affect certain milk components in buffalo milk. Hormones like leptin etc. stimulate signals influencing hypothalamus, thus regulating appetite, feed intake and body metabolism in favor of milk production. Variation in milk component of different districts may be occur due to variation in management practices. The milk 
fat composition is also influenced by feed types making different types of substrates available for synthesis of milk. It suggested that desirable composition of milk may be obtained from animals of appropriate physiological/lactation stage and parity fed with special feed ingredients, in the dairy production system. Genetic makeups of animals are also responsible for difference in milk composition so breeding between good animal is also essential for quality milk production.

\section{References}

Abd El-Salam, M. H. and El-Shibiny, S. 2011. A comprehensive review on the composition and properties of buffalo milk. Dairy Science \& Technology.91: 663-699.

Ahmad, S., Zhang, T., Lee, F., Liu, Y., Li, X. and Guo, M., 2013. Seasonal variations in chemical composition of buffalo milk. Buffalo Bulletin. 32(2): 13241329.

Braun, P.G. and Preuss, S.E., 2008. Nutritional composition and chemicophysical parameters of water buffalo milk and milk products in Germany. Milchwissenschaft. 63(1): 70-72.

Claeys, W.L., Verraes, C., Cardoen, S., De Block, J., Huyghebaert, A., Raes, K., Dewettinck, K. and Herman, L., 2014. Consumption of raw or heated milk from different species: An evaluation of the nutritional and potential health benefits. Food Control. 42:188-201.

Dubey, P.C., Suman, C.L., Sanyal, M.K., Pandey, H.S., Saxena, M.M. and Yadav, P.L., 1997. Factors affecting composition of milk of buffaloes. Indian Journal of Animal Sciences. 67(9):802-804.

Franciscis, D.G., F. Intrieri and B. Mincione. 1988.Milk products from buffaloes. In Proceedings of $2^{\text {nd }}$ World Buffalo
Congress, New Delhi, India. Pp. 641652

Gâjâilă, I., Gâjâilă, G., Dobrea, M. and Cotor, G., 2014. Determination of relationships between milk composition and cheese yield using principal component analysis and logit model. Bull. UASVM Vet. Med. 71:62-65.

Garaniya, N.H., Ramani, H.R. and Golakiya, B.A., 2013. Nutrient profile of Jaffarabadi buffalo milk at different stages of lactation. Asian Journal of Dairy and Food Research. 32(2):168170.

Hamad, M.N.E., El-Moghazy, M.M. and Abdel-Aziz, M.E., 2014. Phenotypic correlations among Egyptian buffalo milk production and its major chemical constituents. J. Agric. Sci. Mansoura Univ.10:1-8.

Javaid, S.B., Gadahi, J.A., Khaskeli, M., Bhutto, M.B., Kumbher, S. and Panhwar, A.H., 2009. Physical and chemical quality of market milk sold at Tandojam, Pakistan. Pakistan Veterinary Journal. 29(1): 27-31.

Johnson R A and Wichern D W. 2002. Applied Multivariate Statistical Analysis. 5th Eds. Pearson Education Ltd.

Mahmood, A. and Usman, S., 2010. A comparative study on the physicochemical parameters of milk samples collected from buffalo, cow, goat and sheep of Gujrat, Pakistan. Pakistan Journal of Nutrition. 9(12):1192-1197.

Malek dos Reis, C. B., Barreiro, J. R., Mestieri, L., Porcionato, M. A. and dos Santos, M. V. 2013. Effect of somatic cell count and mastitis pathogens on milk composition in Gyr cows. BMC Veterinary Research. 9(1):67.

Padghan, P.V., Joglekar, N.V., Thombre, B.M., Khandare, N.O. and Jinturkar, A.S., 2008. Comparative studies on 
physico-chemical properties of marathwadi buffalo milk. Indian Journal of Animal Research. 42(1):6668.

Patbandha, T.K., Ravikala, K., Maharana, B.R., Marandi, S., Ahlawat, A.R. and Gajbhiye, P.U., 2015. Effect of season and stage of lactation on milk components of Jaffrabadi buffaloes. The Bioscan. 10(2): 635-638.

Ravikala, K., Patbandha, T. K. and Vataliya, P. H. 2014. Nutritional management of dairy animals through milk yield and its component evaluation. Proc. of $21^{\text {st }}$ annual convention of Indian Society of Animal Production and Management, January AAU, Anand, Gujarat,India. Pp. 137-144.
Sahin, A., Yildirim, A. and Ulutas, Z., 2014. Some physicochemical characteristics of raw milk of anatolian buffaloes. Italian Journal of Food Science. 26(4): 398.

Yadav, S. P., Sikka, P., Kumar, D., Sarkar, S., Pandey, A. K. Yadav, P. S. and Sethi, R. K. 2013. Variation in milk constituents during different parity and seasons in Murrah buffaloes. Indian Journal of Animal Sciences. 83(7): 747751.

Zaman, G., Goswami, R.N. and Aziz, A., 2007. Milk constituents of swamp buffalo of Assam. Buffalo Bulletin. 26(1): $25-28$.

\section{How to cite this article:}

Choodamani Chandrakar, Praveen Kumar, Sanjay Shakya, Sudhir Kumar Jaiswal, Monika, Upendra Wasist and Sambhuti Shankar Sahu. 2018. Physiochemical Characteristics of Buffalo Milk Samples Available in Four Districts of Chhattisgarh, India. Int.J.Curr.Microbiol.App.Sci. 7(02): 1992-1999. doi: https://doi.org/10.20546/ijcmas.2018.702.238 